Research Article

\title{
Acceptor Comment of Post-Placental Copper T380A Intrauterine Device
}

\section{Komentar Akseptor AKDR Copper T380A Pascaplasenta}

\author{
Eka R Gunardi, Adila RA Malik, Febby Oktavianti, Riry Meria, \\ Fachreza Ardianto, Christina Mariani \\ Department of Obstetrics and Gynecology \\ Faculty of Medicine Universitas Indonesia/ \\ Dr. Cipto Mangunkusumo Hospital \\ Jakarta
}

\begin{abstract}
Objective: To describe the characteristics of subjective complaints reported by post-placental inserted intrauterine device (IUD) acceptor, especially those who used Copper T380A (CU T380A) type of IUD.

Methods: Seventy-two-married women whose age ranged from 19 to 44 years old and received post-placental IUD in Dr. Cipto Mangunkusumo Hospital, Jakarta, were included in this study. Subjective complaints regarding the use of CU T380A IUD were evaluated twice including during the puerperium and six months afterwards by a direct interview.

Results: Most respondents were 20-35 years old, $50 \%$ of whom were primiparous $(n=36)$. There were $42 \%$ respondents reporting pain during insertion, $32 \%$ respondents reporting abdominal pain during the use, $22 \%$ respondents reporting menstrual disorder, $18 \%$ respondents reporting vaginal discharge, and 3\% respondents complaining of having IUD repulsion.

Conclusion: There are variety of subjective complaints reported after post-placental IUD use. However, most of the respondents does not complain anything.

[Indones J Obstet Gynecol 2017; 5-1: 19-22]

Keywords: complication, contraception, intrauterine device (IUD) post-placental, postpartum
\end{abstract}

\begin{abstract}
Abstrak
Tujuan: Untuk mendiskripsikan keluhan subjektif akseptor alat kontrasepsi dalam rahim (AKDR), khususnya jenis Copper T380A (CU T380A) dengan insersi pascaplasenta.

Metode: Kami meneliti 72 perempuan menikah, usia 19-44 tahun, yang menerima insersi AKDR pascaplasenta di RSUPN Dr. Cipto Mangunkusumo Jakarta. Kami mencari keluhan subjektif akseptor AKDR pascaplasenta selama pascasalin dan enam bulan setelahnya dengan wawancara langsung.
\end{abstract}

Hasil: Didapatkan rerata usia responden terbanyak adalah 20-35 tahun, dengan 50\% responden adalah primipara $(n=36)$. Sebanyak 42\% mengeluhkan nyeri saat pemasangan, 32\% mengeluh nyeri perut selama pemakaian, dan 22\% mengeluhkan gangguan mestruasi, sebanyak 18\% mengeluh keputihan, serta sebanyak 3\% ekspulsi.

Kesimpulan: Terdapat beberapa keluhan subjektif pada akseptor AKDR pascaplasenta. Namun, mayoritas responden tidak mengalami keluhan.

[Maj Obstet Ginekol Indones 2017; 5-1: 19-22]

Kata kunci: alat kontrasepsi dalam rahim (AKDR) pascaplasenta, komplikasi, kontrasepsi, pascasalin

\section{INTRODUCTION}

Family planning program can reduce the maternal and infant mortality rate up to $10 \%$ if the couple join the program for a minimum of 2 years. ${ }^{1}$ The short interval between two adjacent labors in a woman was associated with higher maternal and infant morbidity and mortality rate. ${ }^{2}$ Post-placental contraception was an attempt to prevent unwanted pregnancy or short interval between labors in 12 months after delivery. ${ }^{1}$ Postpartum women needed some effective but reversible contraceptive methods to prevent unplanned pregnancy. ${ }^{1,2}$
Among many available choices, Copper T380A ( $\mathrm{Cu}$ T380A) type of intrauterine device (IUD) is one of the most effective and least expensive contraceptive method. It is a non-hormonal contraception that is very effective in preventing pregnancy and it can also be used by most women without interfering the production of breast milk. According to World Health Organization (WHO) $5^{\text {th }}$ edition of Medical Eligibility Criteria, postplacental IUD can be inserted during 48-hour postpartum or 4 weeks afterwards. ${ }^{3-5}$

Intrauterine device is a long-term, reversible, and the most common contraception worldwide. 
It was estimated that more than 160-million women, most of whom came from China and India, were using this contraceptive method. However, the use of $\mathrm{Cu}$ T380A IUD in Indonesia nowadays was decreasing. Different from in 1991, the coverage number of IUD had reached 13\%, those coverage number decreased becoming only $5 \%$ in 2007.

In Indonesia, the use of post-placental IUD had been known for approximately 30 years. ${ }^{6}$ Previous studies concluded that the 3-month compliance of post-placental multiload copper 250 (ML Cu250) type of IUD was $91.1 \%$. The 12-month compliance of post-placental $\mathrm{Cu}$ T380A type of IUD was even higher than that of ML Cu250 (90.17\% vs $87.54 \%$ respectively). ${ }^{7}$ Factors influencing the number of compliance were the assumption of high expulsion rate as well as the existence of side effects, such as pain and bleeding. ${ }^{6,8,9}$ Studies in many countries had shown that the average expulsion rate of postplacental IUD insertion was $11-15 \%$. This number was smaller than those having the IUD inserted late (14-37\%). In Indonesia, the expulsion rate was estimated between $6 \%$ and $10 \% .{ }^{10}$ Apart from timing of post-placental IUD insertion, expulsion event was also affected by the type of IUD and the technique of insertion. ${ }^{11,12}$ Expulsion can be minimalized by having someone professional to insert the IUD correctly and inserting the IUD at the level of uterine fundus. ${ }^{13}$

Nowadays, postpartum contraceptive implementation care, most post-placental $\mathrm{Cu}$ T380A IUD became concerned from all sections. Through good counseling and informed consent, we believed that it would result good compliance for the using of a contraceptive device. ${ }^{14}$ Therefore, this study aims to describe the characteristics of subjective complaints reported by post-placental inserted IUD acceptor, especially those who used CU T380A type of IUD.

\section{METHODS}

A secondary data using descriptive cross sectional study was carried out in the Emergency Room of Obstetrics and Gynecology Department, Dr. Cipto Mangunkusumo Hospital - Faculty of Medicine Universitas Indonesia from July to December 2014.

Women receiving a $\mathrm{Cu}$ T380A type of IUD right after giving birth either vaginally or surgically (cesarean section), being mentally healthy, and having consented were included in this study, while the unavailability of contact number on the medical records was the exclusion criteria in this study.

After randomization, subjects were contacted via telephone to get explanation about the study and to be asked about the consent. After giving consent, subjects would be asked some questions according to the questionnaire. Subjects who cannot be contacted would be considered as drop out and replaced by randomizing other subjects after the target of 12 samples every month were reached.

\section{RESULTS}

Seventy-two women fulfilling the inclusion and exclusion criteria and receiving post-placental IUD in the Emergency Room of Obstetrics and Gynecology Department, Dr. Cipto Mangunkusumo Hospital, were analyzed in this study. Those patients were then asked about their consent and given some questions based on the questionnaire via telephone. The demographics of those patients were displayed on Table 1.

Table 1. Demographic Characteristics of Subjects

\begin{tabular}{lcc}
\hline \hline Variables & n & \% \\
\hline Age (years old) & 4 & 5 \\
$<20$ & 61 & 85 \\
20 - 35 & 7 & 10 \\
$>35$ & & \\
Educational status & 19 & 26 \\
Junior high school & 34 & 47 \\
Senior high school & 9 & 13 \\
Diploma/Associate degree & 10 & 14 \\
Bachelor degree & & \\
Parity status & 36 & 50 \\
Primiparity & 34 & 47 \\
Multiparity & 2 & 3 \\
Grand multiparity & & \\
Method of Labor & 34 & 47 \\
Vaginal delivery & 35 & 49 \\
Cesarean section & 4 & 4 \\
Vacuum extraction & &
\end{tabular}




\section{Frequency of control (times)}

0

1

2

3

Duration of IUD usage (months)

\begin{tabular}{lcc}
$\leq 6$ month & 5 & 7 \\
$\geq 6$ month & 67 & 93 \\
\hline \hline
\end{tabular}

Most patients were 20-35 years old (mean age 28.7 years old) and they had the last educational background of senior high school (47\%). The comparison methods of labor (vaginal delivery and cesarean section) as well as parity status (primiparity and multiparity) were almost equal. While most patients had done follow-up about the IUD usage, $15 \%$ of them did not do the follow-up.

Counselling and decision making about IUD insertion, including factors associated with them, was shown on table 2. Most of the decision making about having IUD inserted was after discussing with her family (63\%). Most patients were satisfied with the choice they made (81\%). Counseling at the point of insertion was done in $68 \%$ of patients and most of them agreed with the idea of IUD insertion (61\%).

There were only a few patients who reported severe pain during IUD insertion (2\%). The most reported complaint was abdominal pain (32\%), followed by menstrual disorder (22\%) and vaginal discharge (18\%). Other complaints, such as sexualrelated disorder (10\%) and IUD expulsion (3\%) were relatively rare. There were $7 \%$ patients using IUD less than 6 months because of expulsion, having abdominal pain or vaginal discharge, and attempting to be pregnant.

Table 2. IUD Counseling and Decision Making

\begin{tabular}{lll}
\hline \hline & $\mathbf{n}$ & $\mathbf{\%}$ \\
\hline Counseling at the time of insertion & & \\
Yes & 49 & 68 \\
No & 23 & 32 \\
Decision of having IUD inserted after counseling & & \\
Yes & 44 & 61 \\
No & 28 & 39
\end{tabular}

Time of decision making

\begin{tabular}{lcc} 
On antenatal care & 12 & 17 \\
Before labor & 28 & 39 \\
After labor & 32 & 44 \\
Decision maker & & \\
Patient's own decision & 0 & 0 \\
Patient and family & 45 & 63 \\
Husband & 9 & 12 \\
Parents & 0 & 0 \\
Others & 18 & 25 \\
Satisfaction of IUD insertion & & \\
Yes & 58 & 81 \\
No & 14 & 19 \\
\hline
\end{tabular}

Table 3. Subjective Complaints after Insertion of PostPlacental IUD

\begin{tabular}{|c|c|c|}
\hline Complaints & $\overline{\mathrm{n}}$ & $\%$ \\
\hline \multicolumn{3}{|l|}{ Pain during insertion } \\
\hline No & 42 & 58 \\
\hline Mild & 24 & 33 \\
\hline Moderate & 5 & 7 \\
\hline Severe & 1 & 2 \\
\hline \multicolumn{3}{|l|}{ Expulsion } \\
\hline Yes & 2 & 3 \\
\hline No & 70 & 97 \\
\hline \multicolumn{3}{|l|}{ Abdominal pain } \\
\hline Yes & 23 & 32 \\
\hline No & 49 & 68 \\
\hline \multicolumn{3}{|l|}{ Menstrual disorder } \\
\hline Yes & 16 & 22 \\
\hline No & 56 & 78 \\
\hline \multicolumn{3}{|l|}{ Sexual-related disorder } \\
\hline Yes & 7 & 10 \\
\hline No & 65 & 90 \\
\hline \multicolumn{3}{|l|}{ Vaginal discharge } \\
\hline Yes & 13 & 18 \\
\hline No & 59 & 82 \\
\hline \multicolumn{3}{|c|}{ Removal of IUD before 6 months } \\
\hline Reason behind removal & 5 & 7 \\
\hline Attempt to be pregnant & 1 & 20 \\
\hline Pain & 3 & 60 \\
\hline Discharge & 1 & 20 \\
\hline
\end{tabular}

\section{DISCUSSION}

Focusing on the use of post placental $\mathrm{Cu}$ T380A type of IUD at Dr. Cipto Mangunkusumo Hospital, 
most patients were satisfied with their contraceptive decision of using that device; even though, many pronouncements were decided right after labor. The most common complaint after IUD insertion was pain and abdominal cramp (32\%). Other IUD insertion complications, such as pain during insertion, menstrual disorder, vaginal discharge, sexual-related disorder, and expulsion of IUD could still be found in a small number of women compared with abdominal pain.

In spite of many subjective complaints reported, majority of patients (81\%) were satisfied with their decision of choosing IUD as the contraceptive method. This result was similar with the one studied in India where more than $90 \%$ of patients were satisfied using IUD in six-month postpartum. ${ }^{12}$ In this study, infection and perforation of the uterus were not found.

Regarding the attempt of contraceptive counseling, there were $32 \%$ of patients who did not get the counseling at the point of IUD insertion. Among 68\% others receiving counseling, most of them were satisfied with the counseling given. Remembering the importance of IUD counseling as well as other general contraception, counseling about contraception must have been given since antenatal care. In counseling, explanation of the importance of follow-up after the insertion of IUD was also needed as there were $15 \%$ of patients who did not have the follow-up after IUD insertion.

Expulsion rate of IUD in this study was only 3\%. This number was smaller than the previous study stating that the expulsion rate of IUD in the first year was about $6-10 \% .^{10}$

The limitation in this study was the unobserved subjective complaints after long-term IUD insertion. This limitation was due to the short time of study, which was 6-to-12-month follow-up after the insertion of IUD. Further study using a longer follow-up time was needed to know more about the long-term subjective complaints of IUD users. Beside the short time of study, this study also only focused on Dr. Cipto Mangunkusumo patients. Multicenter studies with larger sample size were needed to strengthen the accuracy of the result so that it can be generalized in the community in Indonesia. Expansion of post-placental IUD distribution and access accompanied by counseling, right method of insertion, and regular follow-up can be useful to support the successful of postpartum family planning program and decrease both maternal and infant mortality rate.

\section{CONCLUSION}

There are variety of subjective complaints reported after post-placental IUD use. However, most of the respondents does not complain anything.

\section{REFERENCES}

1. Cleland J. Bernstein S, Ezeh A, Faundes A, Glasier A, Innis J. Family planning: The unfinished agenda. Lancet. 2006; 368: 1810-27.

2. Rutstein S. Further evidence of the effect of preceding birth intervals on neonatal, infant, and under-five years mortality and nutritional status in developing countries: Evidence from the demographic and health surveys. DHS Working Papers No. 41. Marco International; 2008.

3. Ross, John A, and William L, Winfrey. Contraceptive use, intention to use and unmet need during the extended post partum period. Int Fam Planning Perspect. 2001; 27(1): 207.

4. Evans A. Postpartum contraception. Woman's Health Med. 2005; 25: 23-6.

5. Stephenson P, Donald PM. Family planning for postpartum women: seizing a missed opportunity. 2005: 15-20.

6. Saifuddin AB. AKDR Post-plasenta. In: Biran A, Mohammad B, Soekami S, editors. Buku Panduan Praktis Pelayanan Kontrasepsi. Edisi 2. Jakarta: Yayasan Bina Pustaka Sarwono Prawirohardjo; 2010. p. MK-78.

7. Morrison C, Waszak C, Katz K, Diabate F, Male EM. Clinical outcomes of two early post partum IUD insertion programs in Africa. Contracep. 1996; 53(1): 17-21.

8. Blanchard H, Mckaig C, ACCESS FP. The IUD: A contraceptive option for postpartum and post-abortion women IUD toolkit 2006.

9. Badan Pusat Statistik, Macro International. Pemakaian alat/cara keluarga berencana. Dalam: Survey Demografi dan Kesehatan Indonesia 2007. USA: BPS dan Marco International; 2008. p. 75.

10. Salem HT, Kamel MA, Mohamed SA, Shaaban OM. Acceptability of Postpartum IUD (PPIUD). Dept OB/GYN, Faculty of Medicine, Assiut University, Assiut, Egypt. 2004; 6: 21.

11. Anggraeni M, Asih L, Hastuty RP. Operasional Research IUD Postplasenta di Rumah Sakit Dr. Cipto Mangunkusumo (RSCM). Jakarta: Puslitbang KB dan Kesehatan Reproduksi BKKBN; 2010. p. 27.

12. Muller AL, Ramos JGL, Martins-Costa SH, Dias RSP, Valerio EG, Hammes LS, et al. Trans vaginal ultrasonographic assessment of the expulsion rate of intrauterine devices inserted in the immediate postpartum period: A pilot study. Contracep. 2005; 72(3): 192-5.

13. Saifuddin AB. Konseling dan persetujuan tindakan medis, Dalam: Biran A, Mohammad B, Soekami S, editors. Buku Panduan Praktis Pelayanan Kontrapsepsi. 2 ed. Jakarta: Yayasan Bina Pustaka Sarwono Prawirohradjo; 2010. p. U1-U7.

14. IUDs: understanding their mechanism of action. Contraception Online-The Contraception Report. 1998; 9(5): 4-8. 